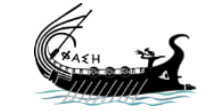

journal.phaselis.org
PHAS LLIS

Issue IV (2018)

\title{
Edebiyatçı Kimliğiyle Quintus Tullius Cicero
}

\author{
Quintus Tullius Cicero As a Man of Letters
}

\author{
Mehmet OKTAN
}

open 2 access journals

The entire contents of this journal, Phaselis: Journal of Interdisciplinary Mediterranean Studies, is open to users and it is an 'open access' journal. Users are able to read the full texts, to download, to copy, print and distribute without obtaining the permission of the editor and author(s). However, all references to the articles published in the e-journal Phaselis are to indicate through reference the source of the citation from this journal.

Phaselis: Journal of Interdisciplinary Mediterranean Studies is a peer-reviewed journal and the articles which have had their peer reviewing process completed will be published on the web-site (journal.phaselis.org) in the year of the journal's issue (e.g. Issue III: JanuaryDecember 2017). At the end of December 2017 the year's issue is completed and Issue IV: January-December 2018 will begin.

Responsibility for the articles published in this journal remains with the authors.

Citation M. Oktan, "Edebiyatçı Kimliğiyle Quintus Tullius Cicero". Phaselis IV (2018) 371-387. http://dx.doi.org/10.18367/Pha.18023

Received Date: 16.11.2018 | Acceptance Date: 12.12.2018

Online Publication Date: 30.12.2018

Editing Phaselis Research Project

www.phaselis.org 


\title{
Edebiyatçı Kimliğiyle Quintus Tullius Cicero
}

\author{
Quintus Tullius Cicero As a Man of Letters
}

\begin{abstract}
Mehmet OKTAN*
Öz: Quintus Tullius Cicero kendisine ilham kaynağı olabilecek veya edebi açıdan kendisinin gelişimine katkı sağlayabilecek Cicero gibi bir ağabeye sahiptir. Onunla birlikte iyi bir eğitim aldığı için Yunan edebiyatı ile felsefesine çok vakıftır ve Roma dışında 7 yıl kadar idari görevlerde bulunması hariç tutulursa hayatını çoğunlukla onunla geçirmiştir. Bu durumda yazım konusunda kendisinin de onun gibi büyük bir yetkinliğe ulaşması ve çok üretken bir yazar olması beklenebilir. Nitekim Cicero'dan ve diğer antik yazarlardan kendisinin dikkate değer özellikte bir şair olduğu öğrenilmektedir. Buna karşın çoğunlukla Roma dışındayken yazdığı şiirlerinin muhtemelen kaybolacağına dair bir endişe taşımaması nedeniyle, bunları tek nüsha olarak yazdığı ve aynı duygu yoğunluğuyla tekrar yazamadığı veya üstlendiği vazifelerin yanı sıra yaşanan gelişmeler nedeniyle üzerlerinde tekrar durma fırsatı yakalayamadığı için bunlar günümüze kalmamışlardır. Bu durum çalışmalarının özgünlük düzeyinin anlaşımasını engellemiş ve eserlerin taşıdığı başılılar bunların Yunanca'dan Latince'ye uyarlama veya çeviri olduğu düşüncesine yol açmıştır. Günümüze tam veya bir kısmı kalan eserlerini ise, uyarlama veya çeviri olabilecek çalışmalarının da etkisiyle, başta ağabeyi olmak üzere diğer yazarlara atfetme eğilimi bulunmaktadır. Bu çalışmada, mevcut eserleri ve ağabeyi ile diğer antik yazarların kendisi hakkında verdiği bilgiler doğrultusunda Quintus Tullius Cicero'nun edebiyatçı kimliği ele alınacaktır. Az sayıda edebi faaliyette bulunmasının nedenlerinin daha iyi anlaşılabileceği düşüncesiyle çalışmada kısa bir şekilde kendisinin hayatına da yer verilmiştir.
\end{abstract}

Anahtar Sözcükler: Quintus Tullius Cicero, Marcus Tullius Cicero, Latin Edebiyatı.

Abstract: Quintus Tullius Cicero had an elder brother who could inspire and contribute in terms of literature to his development, being Cicero. In addition, Quintus Tullius obtained a very good education becoming a master of Greek literature and philosophy, and he spent most of his life in Rome together with him, with the exception of 7 years when he served in administrative positions outside of Rome. For that reason his writing was naturally expected to be excellent and that he would become a very productive writer. Indeed, it is known from Cicero and from other ancient writers that he was a poet of noteworthy ability. Although his poems were mostly written in Rome, it was probably due to the fact he wasn't concerned that they would be lost, that he wrote all his works only as single copies to his brother and he couldn't rewrite them again when they were lost so as to carry the same intensity of feeling as in the first copy. The loss of these works has prevented the full understanding of the poetic level he reached and the titles they carry indicate that these works were adaptations made from Greek to Latin, or were translations. In consequence many have thought these works lacked originality although this was probably not the case. The rare examples of his work, of which some part, or, all of a work, remain to the present day, have often been attributed to other writers, especially to his older brother, in consequence of his area of study, producing works of adaptation or translation. In this study, from the surviving remains of his works and from indications of his lost works, together with the information provided by his brother and by other ancient authors, the literary identity of Quintus Tullius Cicero is examined. To better understand the relationship between his life and his works an account of his life is also included, which provides reasons why his literary output was not greater than it was.

Keywords: Quintus Tullius Cicero, Marcus Tullius Cicero, Latin Literature.

* Dr., Akdeniz Üniversitesi, Edebiyat Fakültesi, Eskiçağ Dilleri ve Kültürleri Böl., Antalya. mehmetoktan@akdeniz.edu.tr Bu çalışma 27-29 Ekim 2018 tarihlerinde düzenlenen Asead IV. Uluslararası Sosyal Bilimler Sempozyumu'nda aynı başlıkla sunulan sözel bildirinin genişletilmiş halidir. 
Quintus Tullius Cicero aedilis ve praetor olarak görevini 100 yılında doğan ${ }^{1}$ C. Iulius Caesar ile birlikte icra etmesine rağmen, kendisinin 102 yılında doğduğu düşünülmektedir². Eğitimine başlayıncaya kadar, doğduğu Arpinum'da ${ }^{3}$ yaşayan Quintus, ağabeyinin 79-77 yılları arasında Atina'ya, Asia Eyaleti'ne ve Rhodos'a yaptığı eğitim gezisine iştirak etmiştir ${ }^{4} .70$ yılı dolaylarında, ağabeyi Cicero'nun teşviki sonucunda, onun en yakın arkadaşı Titus Pomponius Atticus'un kız kardeşi Pomponia ile evlenmiştir. Ancak kendisinden birkaç yaş büyük olan Pomponia'ya karşı davranışları nedeniyle zaman zaman Cicero'nun da sitem edip uyardığı Quintus genel olarak geçimsizlik yaşadığı eşinden 44 yııında boşanmıştır. Pomponia ile evliliğinden 66 yılında doğan ve kendi adını taşıyan bir oğlu bulunmaktadır. Cicero'nun eserlerinde Roma'dan uzun süreli uzaklaştığına dair bir bilgi olmamasına karşın ${ }^{5}, 70$ veya 68 yılında bir eyalette quaestor olduğu düşünülmektedir ${ }^{6}$. Böylelikle senatusa adım atan Quintus 65 yılında aedilis plebis olmuştur ${ }^{7}$. 63 yılının Aralık ayında ağabeyini Catilina ile mücadele etmeye teşvik etmiş ve ölüm cezasını benimsemeyen Caesar'a cephe almıştır ${ }^{8} .62$ yılında Caesar ile birlikte praetor olarak hizmette bulunmuş ve muhtemelen kendisine praetor urbanus birimi düşmüştür ${ }^{9}$. Ağabeyi şair Arkhias'। 62 yılında savunduğu esnada da kendisinin yargıç koltuğunda oturduğu sanılmaktadır ${ }^{10}$. Görevine başladığı 62 yılının hemen başlarında Bruttium'da Catilina'nın geride kalan taraftarlarıyla mücadele etmiştir ${ }^{11}$.

Praetor olarak hizmet ettikten sonra, Mithradates VI ile yapılan savaşların ardından ekonomik gücünü henüz yeterince toparlayamadığı için, oldukça az bir öneme sahip olan ${ }^{12}$ Asia Eyaleti'nde propraetor olarak görev yapmıştır. Esasen bir yıl olan görevini tamamlayınca geri dönmesi gerekmesine ve hem kendisinin bu yönde bir arzusu olmasına hem de ağabeyi bu hususta kendisine yardım etmeye çalışmasına karşın, bu sıralarda başka valilerin durumunda olduğu üzere ${ }^{13}$, görevi iki kez uzatılmıştır ${ }^{14}$. Eyalet sakinleri açısından valilik görevini iyi bir şekilde

1 Metin içerisindeki tüm tarihler aksi belirtilmediği sürece milettan öncesine aittir.

2 Kariyeri sırasında yerine getirdiği görevleri C. Iulius Caesar ile birlikte yaptığı için normalde onunla aynı yaşta olması beklenmektedir. Bununla birlikte ikisi aynı sınıftan değildir. Bu nedenle atlı sınıfına mensup kendisi aynı yı içerisinde aedilis plebis olarak görev yaparken, Caesar patricii sınıfına yani asil bir soya mensup olduğu için aedilis curulis olarak görev yapmıştır. Kariyer sırasında homo novus kimselerle patricii sınıfına mensup kimselerin arasında iki yıl kadar fark olabildiği için, Q. Tullius'un doğum yılı 102 yılı olarak kabul edilmektedir. Doğum tarihi için ayrıca bk. Kasten 1965, 162.

Cic. leg. 2. 1 ; 2. 2; 2. 3.

Cic. fin. 5. 1.

Krş. McDermott 1971, 708.

Münzer 1948, 1287; McDermott 1971, 712 vd.

Cicero, seçimde kardeşine destek sağlaması için, yakın arkadaşı Atticus’tan yardım istemiştir Cic. Att. 1. 4.

Plut. Cic. 20. 2-3. Krş. Suet. Iul. 14. 2.

McDermott 1971, 702 vd.

10 Schol. Bob. 175. 29-32; Cic. Arch. 2. Ancak Brennan (2009, 435) Quintus'un bu esnada praetor urbanus olarak görev yapmasına kuşkuyla yaklaşmaktadır.

11 Oros. hist. 6. 6. Krş. Cass. Dio 37. 41. 1.

12 L. Valerius Flaccus'un 90 yılındaki valiliği ardından 86 yılında consul suffectus olması haricinde, praetor olarak hizmette bulunduktan sonra Asia Eyaleti'nde valilik yapanların 45 yıl gibi çok uzun bir süre consul olamadıkları görülmektedir. Bunlardan birisi de Quintus olmuştur. Bu durum bu eyaletin valilere kariyerleri için büyük bir fırsat sunmadığını göstermektedir. Ayrıca bk. Wiseman 1966, 111. Cicero gibi bir ağabeyi olmasına ve Roma'nın en önde gelen kimseleri olan Pompeius ile Caesar komutasında legatus olarak görev yapmasıyla büyük bir avantaja sahip olmasına rağmen, ağabeyinin de kendisine güçlü bir şekilde destek vermemesinden dolayı kendisinin consul olma girişiminde bulunduğu bilinmemektedir.

13 Örnekler için bk. Brennan 2000, 493 vd.

14 Cicero Att. 2. 4; 2. 16; Cic. QFr. 1. 1. 1; 1. 1. 2 
tamamlamasıyla 58 yılının Nisan ayı sonlarında Ephesos'tan Roma'ya dönüş için yola çıkarken, aynı zaman diliminde ağabeyi Cicero ise sürgüne gitmek üzere Brundisium'dan ayrılmıştır ${ }^{15}$. Dönüşü Roma'daki havanın, ağabeyinin ve kendisinin tamamen aleyhine döndüğü bir zamana denk gelen Quintus, ağabeyinin başına gelenlerden çok fazla etkilenmiştir. Hatta ağabeyinin evi Clodius vasıtasıyla yıktırılırken, kendisinin evi de, onun evine komşu olduğu için zarar görmüştür $^{16}$. Ayrıca bu yılda çıkan bir kargaşa esnasında yaralanmış ${ }^{17}$ ve eyalet valiliği yaptığı için büyük bir avantajı da olmasına karşın, ağabeyine yönelik oluşan olumsuz hava nedeniyle consul adayı bile olmamıştır. Hatta ağabeyinin düşmanları tarafından eyaletteki görevi sırasındaki tutumu nedeniyle mahkemeye verilmek istenmiş ancak bundan bir sonuç çıkmamışır ${ }^{18}$.

Kendisine karşı yapılan bu tür girişimlerden sonra, sürgünde büyük bir çöküntü yaşayan ağabeyi ile Pompeius arasındaki buzların erimesi amacıyla büyük bir çaba göstermiştir. Bunun yanında, ağabeyinin geri dönüşü için veya en azından dönüş girişimlerine köstek olmaması adına, ağabeyini pek sevmemesine karşın dönemin diğer bir nüfuzlu kişisi Caesar'ın desteğini alabilmek amacıyla ona birçok taahhütte bulunmuştur ${ }^{19}$. Başta canı pahasına hareket eden kendisinin ${ }^{20}$ ve Pompeius ile yakın dostlarının girişimleri sayesinde, Clodius haricinde herkesin fikir birliği içinde olduğu bir hareket sonucunda ağabeyi 4 Ağustos 57 tarihinde alınan bir kararla ${ }^{21} 4$ Eylül 57 tarihinde Roma'ya geri dönmüştür. Quintus'a buradan çıkan sonuç, istemeyerek de olsa, olası consul seçiminde desteğinden mahrum kalmamak amacıyla minnet borcunu ödemek olmuştur. Buna bağlı olarak 8 Eylül 57 tarihinden 56 yılının Haziran ayına kadar praefectus annonae olarak görevlendirilen Pompeius'un komutasında Sardinia'da legatus olarak görev yapmıştır ${ }^{22}$. Mektuplarında bu görevinden bir an önce dönmesini dile getiren ağabeyini, Caesar'ın da tepkisini çeken lex Campana isimli düzenlemeye olan desteğinden ${ }^{23}$ vazgeçirmek ve Caesar'a karşı girişimlerinde daha dikkatli olmasını bildirmek üzere 56 yılının Mayıs ayı ortalarında geri dönmüştür ${ }^{24}$. Daha sonra ise hem zenginleşmek, hem taşınmaz mülkleri üzerine yapılan masraflardan kaynaklanan borçlarını ödemek hem de olası consul adaylığı sırasında desteğini sağlamak amacıyla 54 yılı Mayıs ayı başından 52 yılı sonlarına kadar legatus olarak bu defa Caesar'ın komutasında Gallia'da ve Britannia'da ikinci kez yürütülen seferlere katılmıştır.

52 yılı sonlarında geri dönen Quintus Roma'da yine çok fazla kalamamıştır. 51 yılı için Cilicia Eyaleti valiliğini yürütecek olan ağabeyi askeri işlerden anlamadığından dolayı, legatus olarak

15 Cic. Att. 3. 8. 1; 3. 9. 1. Ayrıca değerlendirmeler için bk. Münzer 19481292.

16 Cic. Att. 4. 1; 4. 3; Cic. Cael. 78; Cic. Mil. 87. Krş. Cic. Dom. 62; Cic. Sest. 54; Cic. QFr. 2. 3. 7; Cic. Pis. 26; Cass. Dio 38. 17. Ağabeyinin evi Cicero sürgünden döndükten sonra devlet bütçesiyle onarıldığı ve Quintus'un evi de bizzat Clodius'un girişimiyle zarar görüğü için, kendisinin zararlarının da karşılandığı düşünülebilir. Cic. Att. 4. 1; 4. 3; Plut. Cic. 33; Liv. 104; App. civ. 2. 16. Krş. Cic. Red. Sen. 1; Cic. QFr. 2. 4. 2.

17 Plut. Cic. 33. 4.

18 Cic. Att. 2. 4; 3. 1; 3. 8. 2-3; 3. 9; 3. 13; 3. 17; 3. 19; 3. 23; Cic. QFr. 1. 3. 5-6; 1. 4. 2; 1. 4. 5; Cic. Sest. 68; Cic. Dom. 59; 96.

19 Cic. Fam. 1. 9; Cass. Dio. 39. 10. Ayrıca bk. Cic. Sest. 71.

20 Cic. QFr. 2. 3; Cic. Sest. 68; 76; 145; Cic. Red. Sen. 37; Cic. Red. Quir. 5; 8; Cic. Dom. 59; Plut. Cic. 33. .

21 Cic. Att. 4. 1; Cic. Red. Sen. 1; 2; 3; 5; Cic. Red. Quir. 10; 18; Plut. Pomp. 49. 58 yılı ortalarından itibaren başlayan girişimler için bk. Cic. Att. 3. 23; 3. 26. Cic. Sest. 69-72; 74; 116; 128; Cic. Fam. 14. 3; Cic. Red. Sen. 25; 26; 27; Cic. Pis. 25; 27; 34; 35; 76.

22 Cic. QFr. 2. 1. 3; 2. 2. 1; 2. 5. 5. Cic. Scaur. 39; Aslında bu görev, Pompeius'un görevlendirilmesini sağlayan Cicero'ya teklif edilmiştir. Ancak o reddetmiştir. Cic. Att. 4, 1; 4.2.

235 Nisan 56 tarihinde Cicero tarafından düzenleme üzerine yapılan konuşma hakkında bk. Crawford 1984, $152 \mathrm{vdd}$

24 Cic. QFr. 2. 2. 4; 2. 3. 7; 2. 5. 3; 2. 6. 3; Cic. Fam. 1. 9. 9-10. 
kardeşini seçmiş ve her ikisi de oğullarını beraberinde alarak yola çıkmıştır ${ }^{25}$. Quintus gerek normalden daha fazla süren valiliği sırasında, gerekse de iki büyük komutanın yanında iki kez legatus olarak görev yapması sayesinde büyük bir deneyim sahibidir. Eyalet sınırlarına 51 yııının Ağustos ayı başlarında ayak basmış ve bu görevi sırasında, Sonbahar aylarında Pindenissum kenti yakınlarındaki dağlık bölgelerde bulunan yerel kavimlere karşı yürütülen askeri mücadelelerde ağabeyine büyük bir katkı sağlamıştır. Eyaletin sınırları çok geniş olduğu ve bölge Roma açısından sorun teşkil edebilecek halklarla komşu olduğu için, buradaki görev süresi boyunca sürekli hareket halinde olmuştur. Eyalet valisiz kalacak olmasına rağmen, bir yıllık görev süresi dışında daha fazla kalmak istemeyen Cicero yeni vali atamasının gecikmesi üzerine eyaletten ayrıldığı halde ${ }^{26}$, Quintus buradaki kavimlerle mücadeleyi sürdürmüştür. Cicero kardeşinin de Roma'ya dönmesinin ardından Amanos Dağları'nda kazandıkları başarıları kutlama düşüncesinde olmasına karşın, gerek kendilerine karşı takınılan olumsuz tutum gerekse de devamında iç savaş çıktığı için bu arzu gerçekleşmemiştir.

Roma'da olduğu 49 yılından itibaren Romalılar, Caesar ve Pompeius taraftarı olarak ikiye ayrılmıştır. Esasında Quintus 64 yılında, consul olmak için adaylığını koyan ağabeyine yaptığı tavsiyelerde, optimates kesimi karşısına almamak adına, halkçı olan Pompeius ile seçim sürecinde çok içli dışlı olunmaması gerektiğini tavsiye etmiştir. İç savaş sürecinde de Pompeius konusunda ağabeyiyle tam bir fikir birliği içerisinde olmamakla birlikte, ağabeyi Cicero'nun aldığı nihai karar ardından 7 Haziran'da Pompeius'a katılmak için yola çıkmışıı ${ }^{27}$. Kendisinin iç savaş sırasındaki faaliyetleri bilinmemektedir ve ağabeyinin mektuplarından da kendilerine dair çok fazla bilgi elde edilememektedir. Buna karşın 48 yılı başlarında Yunanistan'da oldukları ve yaz boyunca Pompeius'un ordugahında oldukları anlaşılmaktadır ${ }^{28}$. Pompeius ile Caesar arasında yapılan savaş sırasında ise, ağabeyinin hastalığı ${ }^{29}$ nedeniyle oğluyla birlikte onun yanında kalmış olmalıdır. Pompeius'un 9 Ağustos 48 tarihinde Pharsalos'ta gerçekleşen savaşı kaybetmesi ve Caesar'a karşı artık başarı kazanılabileceğine dair bir ihtimalin kalmaması, hem Cicero ve ailesi hem de kardeşi ile onun ailesi için olumsuz yönde giden büyük değişimlerin başlangıcı olmuştur. Bu durum nedeniyle, iç savaş sürecinde belirsiz bir şekilde olsa da, iki kardeşin beraber hareket etme olayı son bulmuş ve her zaman çok sıcak bir ilişkiye sahip iki kardeşin arası tamamen açılmıştır ${ }^{30}$.

Cicero Pharsalos'taki yenilgiden sonra Pompeius taraftarlarını terk edip Brundisium'a geri dönerken, 4 Kasım 48 tarihi civarında oğluyla birlikte Cicero'dan ayrılan Quintus ise 27 Kasım'da muhtemelen oğluyla birlikte, Pompeius'u takip eden Caesar'ın arkasından gitmiştir ${ }^{31}$. Quintus, Antiokheia kentinde Caesar ile görüşen oğlu vasıtasıyla 47 yılı yazında kendisini affettirmeyi başarmıştır. Quintus oğlu vasıtasıyla kendisinin affedilmesini sağlarken, Caesar'ın Cicero'yu da affetmesi ardından bir yılı aşkın bir süre ${ }^{32}$ birbirlerine küs olan iki kardeşin arası tamamen eskisi

Cic. QFr. 1. 4. 5; Cic. Att. 5. 14. 1-2; 5. 15.1.

26 Kardeşi legatus olarak daha kıdemli olmasına ve 50 yılının Haziran ayına kadar bölgede kalmasına rağmen, Cicero kardeşini bırakması durumunda oluşacak dedikodulardan kaçınmak için vekil vali olarak onun yerine hem genç bulduğu hem de yetenekli birisi olarak görmediği quaestor C. Coelius Caldus'u bırakmıştır.

27 Cic. Att. 8. 11. Kendisi ağabeyinin Pompeius'u Yunanistan'da ziyaret etmesinin sorumlusu olarak gösterilmiştir. Bk. Cic. Att. 11. 12.

28 Cic. Att. 11. 1; 11. 2; 11. 3; Cic. Fam. 8. 17.

29 Cic. Att. 11. 4; Cic. Fam. 9. 18. 2; Plut. Cic. 39.

30 Cic. Att. 11. 5. 3-4.

31 Cic. Att. 11. 5. 3-4; 11. 6. 6.

32 Cicero ile Quintus arasındaki soğukluk Eylül ayı başlarında da devam etmektedir. Cic. Att. 11. 22.1. 
kadar olmasa da düzelmiştir. Quintus, Caesar'ın öldürülmesi üzerine oğluyla birlikte Brutus saflarında yer almışıır ${ }^{33}$ ve ailecek M. Antonius'a karşı cephe almışlardır ${ }^{34}$. Lakin bu süreçte ağabeyi Cicero'nun M. Antonius'a karşı çok sert bir tutum izlemesi kendi sonlarını getirmiştir. Başlangıçta Cicero ile iyi ilişkiler kuran Octavianus'un Antonius ile yeni kurduğu ilişkisini güçlendirmek adına Cicero'yu feda etmesi nedeniyle, Quintus da oğluyla birlikte 43 yılının Aralık ayında kara listeye alınmıştır. Bunun üzerine ağabeyi ile birlikte hemen kaçmak için vedalaşmasına karşın, kendisini aramaya çıkan hizmetçileri tarafından aldatılmış ve 43 yılının sonlarında oğlu ile birlikte öldürülmüştür ${ }^{35}$.

Cicero'nun Quintus'a Asia Eyaleti valisi olduğu esnada gönderdiği mektuplardan, kendisinin sabırsız ve çok çabuk sinirlenen bir kimse olduğu anlaşılmaktadır ${ }^{36}$. Bununla birlikte ağabeyi Cicero her zaman kardeşine sahip çıkmış ve ona destek olmuştur. Quintus Roma dışında görev yaparken de, onun dönüşünü her defasında sabırsızlıkla beklemiştir ${ }^{37}$. Genelde birlikte bir yaşam sürmelerine paralel olarak neredeyse aynı yaşlarda olan çocukları da benzer bir eğitim sürecinden geçmiş ve beraber büyümüşlerdir. Quintus görev için Roma dışında olduğu zamanlarda da, ağabeyi kendisinin gerek oğluyla gerekse de diğer şahsi sorunlarıyla yakından ilgilenmiştir ${ }^{38}$. Pompeius ile Caesar arasında gerçekleşen iç savaş sonrasında kısa süreli fikir ayrılığı yaşadıkları ve birbirlerine düşmanca bir tutum sergiledikleri dönem hariç tutulursa birbirleriyle çok iyi anlaşmışlardır.

Quintus'un tam olarak ele geçen tek çalışması 64 yılına aittir. Bu nedenle en iyi çıkarım veya değerlendirme bu eseri hakkında yapılabilmektedir. Eser de Petitione Consulatus Liber adıyla da bilinmekle birlikte, genellikle Commentariolum Petitionis başlı̆̆ıyla karşımıza çıkmaktadır. Seçim Kampanyası Kitapçı̆̆ı ${ }^{39}$ olarak adlandırılabilecek bu eserin neredeyse tamamı consul adayı bir kimsenin yapacağı seçim yarışmasına ve seçim sürecine ayrılmıştır. Çalışma bu yönüyle tek olma özelliği taşımaktadır. Quintus consul adayı olan ağabeyi Cicero'nun bu seçim sırasındaki işlerini kolaylaştırmak, işin içinde olması dolayısıyla onun göremeyecek olduğu şeyleri hatırlatmak adına ona iyi bir seçim kampanyasının nasıl yürütülmesi ve bu süreçte ne gibi yöntemlerin izlenmesi gerektiğini tavsiye etmektedir. Bu nedenle eserin içerisindeki unsurlar çoğunlukla, sadece consul seçimine katılacak bir aday ve Quintus'un eserinin 58. paragrafında ifade ettiği gibi, özellikle de Cicero için çok daha uygundur. Bununla birlikte çalışma consullük seçimine adaylığını koyan Cicero özelinde olsa da, eser sayesinde Geç Cumhuriyet Dönemi'nde consullük için yapılan seçim yarışının neler üzerine şekillendiği, bunun nasıl yürütülmesi gerektiği, seçimleri kazanma stratejisi, dönemin politik koşulları, 64 yılı civarında Roma'da gerçekleşen olaylar ile önde gelen şahıslar hakkında önemli bilgiler elde edilmektedir. Bunun yanında eserde bir seçim yarışı sırasında

33 Cic. Att. 15. 21.

34 M. Antonius'un, Quintus'un oğlunun kendi babasını ve amcasını öldürmeyi tasarladığını belirtmesinden kendilerinin ailecek Antonius'a karşı oldukları anlaşılmaktadır. Cic. Phil. 3. 17; 3.18.

35 Plut. Cic. 47. 4; App. civ. 4. 19-20; Cass. Dio 47. 10. 6-7.

36 Mektuplarda geniş yer verilen bu sorun özellikle görevinin ilk yılında bir şikâyet unsuru teşkil ediyorken, ikinci yılında bununla mücadelesinde başarılı olduğuna dair övgüler bulunmaktadır. Bk. Cic. QFr. 1. 1. $37 ; 1$. 1. $38 ; 1.1 .39 ; 1.1 .40$.

37 Cicero kardeşi Quintus'un 61 yılında başlayan Asia valiliğinin uzatılmaması ve onun biran önce Roma'ya dönmesi için de teşebbüslerde bulunmuştur. Ancak bunda başarısız olmuş ve kardeşi 58 yılının Mayıs ayına kadar valilik yapmıştır. Cic. QFr. 1. 1. 1-2; Att. 2. 4. 2; 2. 6. 2; 3. 9. 1. Ayrıca bk. Cic. Att. 2. 16. 4.

38 Cic. QFr. 2. 4. 6; 2. 5. 6; 2. 13. 2; 3. 1. 7; 3. 1. 14; 3. 1. 19; 3. 3. 1; 3. 3. 4. Cicero da (Fam. 14. 1. 4-5) sürgünde olduğu sırada kardeşi ailesiyle sorun yaşadığı zaman, ailesine sayıları az olduğu ve birbirlerinden başka kimseleri olmadığı için birbirlerine olabildiğince sahip çıkmalarını istemiştir.

39 Krş. Telatar - Ak 2009, 127. 
adaylar tarafından izlenmesi gereken yöntemlere dair, her dönem geçerliliğini koruyacak ve her seçimde kullanılabilecek taktikler ile tavsiyeler verilmektedir. Yine de sadece bu eserdeki bilgiler doğrultusunda, antik dönemde Roma'da yürütülen seçim kampanyası ve sistemi üzerine kesin bir hükme varmak mümkün değildir. Zira söz konusu metin böyle bir amaç taşımak yerine, yazarın kendisinin de belirttiği üzere, büyük ölçüde ağabeyi Cicero'nun bu süreçte nasıl başarıya ulaşabileceğine odaklanmaktadır.

Bu eserin Quintus tarafından ağabeyine ne zaman hazırlanıp gönderildiği bilinmemektedir. Bununla birlikte ağabeyine, eserinde ısrarla rakiplerine karşı yargı yolunu takip etmesini ve hem onları hem de onların yandaşlarını bu yolla korkutmasını önermektedir. Muhtemelen Quintus bu eserini yazdığı sırada, 64 yılında gündemde olan ve seçimlerdeki usulsüzlüğü kaldırmaya yönelik olan yeni yasanın henüz farkında değildir veya büyük ihtimalle yeni yasayı çıkarmaya yönelik girişimler henüz başlamamış gözükmektedir. Buna bağı olarak kendisinin yazıp göndermiş olduğu bu metin büyük ölçüde yeni rüşvet yasasının çıkarılma sürecinden veya en azından söz konusu yasa teklifinin $Q$. Mucius Orestinus tarafından veto edilmesinden önce yazıımış olmalıdır. Bu durumda Quintus'un bu gelişmelerden haberdar olmadığı düşünülebilir. Ayrıca Cicero'nun seçim öncesinde senatusta yaptığı ve rakipleri Catilina ile Antonius'u hedef aldığı önemli konuşmasında Quintus'un tavsiyelerinden ve olayları açıklamak amacıyla kullandığı bazı örneklerden yararlanmış olması, bunun normalde Temmuz ayında gerçekleştirilen consul seçimlerinden çok daha önce kendisine ulaştırıldığını göstermektedir ${ }^{40}$.

Quintus eserinin sonunda, kardeşinin bundan yararlanıp yararlanmayacağına dair duyduğu kuşkuyu dile getirmiştir. Ayrıca eserinin kusursuz olması ve ilerleyen zamanlarda başkalarının da kendi seçim kampanyalarında bunu kullanabilmesi için, kardeşinden eksik bulduğu noktaları kendisine belirtmesini istemiştir. Cicero'nun, kendisi için hazırlanan bu esere yönelik bir eleştirisi veya düşüncesi bilinmemektedir. Buna karşın bu eser içerisindeki bazı bölümler ile Cicero'nun 64 yılındaki consullük seçiminden çok kısa süre önce senatusta verdiği in Senatu in Toga Candida contra C. Antonium et L. Catilinam Competitores ve 63 yılında yine senatusta verdiği pro Murena isimli söylevleri arasında ifade ve anlatım açısından büyük benzerlikler bulunmaktadır. Bunun yanında 44 yılında kaleme aldığı de Officiiis ${ }^{41}$ isimli çalışmasında ve yer yer diğer eserlerinde Quintus'un ifadeleriyle paralellikler bulunmaktadır. Bu nedenle Cicero'nun bu eserden epeyce yararlandığı anlaşıımaktadır. Ayrıca bu çalışmadaki bazı ifadelerin benzeri veya aynısı, bazen başka yazarların çalışmalarında da kullanılmıştır ${ }^{42}$. Cicero'nun eserlerinde Quintus'un ifadeleriyle benzerlikler olması ve zamanını çoğunlukla ağabeyi ile birlikte geçirdiği için gerek gözlem gerekse de kendisini en iyi tanıyan kimse olarak ağabeyine tavsiye açısından kendisinin önemli bir yetkinliğe ulaşması gayet normal gözükmektedir. Bununla birlikte Quintus'un, consullük öncesindeki en önemli makam olan praetorluk seçimine bu esnada henüz katılmamış olması ve ancak bir consul adayının deneyim sahibi olabileceği kapsamlı tavsiyelerde bulunması nedeniyle, bu deneyimlere nasıl ulaşıldığı sorgulanmış ve eserin aidiyetliği konusunda bilim dünyasında büyük bir fikir uyuşmazlığı yaşanmıştır.

40 Eserin ne zaman yayınlandığı kesin olmamakla birlikte, bunun üzerine ayrıntılı bir inceleme yapan M. C. Alexander (2009b, 390) söz konusu bu eserin iki kardeşin ömrünün sonlarına doğru veya 43 yılındaki ölümlerinden sonra yayınlandığını düşünmektedir.

41 Benzerliklere örnek olarak bk. Q. Cic. Comm. Pet. 16 = Cic. Off. 1. 54; 1. 58; Q. Cic. Comm. Pet. 19 = Cic. Off. 1. 48; Q. Cic. Comm. Pet. 20 = Cic. Off. 2. 51; 2.70.

42 Bu eser ile Cicero'nun kendi eserleri veya başka çalışmalar arasında bulunan benzer noktalar ve bunların detaylı olarak değerlendirilmesi üzerine bk. Tyrrell 1885, 110 vdd.; Hendrickson 1892, 203 vdd.; Hendrickson 1903, 4 vdd; Balsdon 1963, 242 vdd.; Waibel 1969, 12 vdd. ve 53 vdd.; Nardo 1970, 3 vdd. 
Söz konusu bu önemli eserin yazarına veya yazımına yönelik olarak günümüze kadar yapılan üç farklı değerlendirme bulunmaktadır. Bir kısım bilim insanı eserin giriş kısmının Quintus kardeşi Marcus'a selam eder olarak başlamasından ve eserin sonunda uygun görmediği bir yer olması durumunda bunu kendisine belirtmesi isteğinden de anlaşılacağı üzere bunun Quintus tarafından yazıldığını ifade etmiştir ${ }^{43}$. Çalışmadaki bazı bölümlerin Cicero'nun ifadeleriyle yakın benzerlik göstermesi yanında, Quintus'un bu tür bilgileri tecrübe etmesini sağlayacak praetor ve consul adaylığını henüz gerçekleştirmemiş olmasından dolayı, bu tür tavsiyeleri yapmaya yetkin bir kimse olmadığı düşüncesini taşıyan bir kısım bilim insanı bunun Cicero'nun kendisi tarafından yazıldığını ileri sürmüştür. Bir diğer görüşte ise, eserde tutarsız görülen bazı bilgilerin de etkisiyle, MS. I. yüzyılda başkasının ağzından kaleme alınan eserlerin varlığına ve bunun o sırada bir gelenek halini almasına bağlı olarak, bu metnin MS. I. yüzyıldaki bir evrede başkası tarafından ${ }^{44}$ yazıldığı iddia edilmiştir. Bir başka kesim eserin Quintus'a ait olmadığını kabul etmesine karşın ${ }^{45}$, çalışmanın yazarı veya tarihi üzerine net bir tespitte bulunmaktan kaçınmıştır. Bu görüşteki bilim insanları eserin yazarı üzerine yapılan tartışmalara katılmak yerine, eserin Geç Cumhuriyet Dönemi'nde seçim sisteminin nasıl işlediğine dair bilgiler vermesinden dolayı taşıdığı önemi ön plana çıkarmışlardır. ${ }^{46}$ Eser üzerine yakın zamanlarda kaleme alınan çalışmalarda, bunun yazarı olarak çoğunlukla Quintus zikredilmekte ${ }^{47}$ ve eserin çevirisinin yapıldığı çalışmalarda da bu yönde bir anlayış bulunmaktadır. Bununla birlikte eser hakkında yakın zamanlarda yapılan ayrıntılı incelemelerde, halen metnin yazarın sorgulanması ve bu kişinin Quintus olmadığı düşüncesini benimseme anlayışı devam etmektedir ${ }^{48}$.

Yukarıda da belirtildiği üzere, Quintus bu eser yazıldığı sırada, içerisinde verilen bilgilerin en iyi şekilde tecrübe edilebileceği praetor ve patricii sınıfına mensup olmayan şahıslar için çok büyük bir çabanın gösterilmesi gerektiği consul seçimlerine katılmamıştır. Bununla birlikte ağabeyi Cicero da henüz bir eyalette valilik yapmamasına rağmen, Asia Eyaleti'nde vali olarak görev yapan kardeşine görevi sırasında yazdığı mektupların büyük bölümünde eyalet yönetimi üzerine tavsiyelerde bulunmakta, yönetimi sırasında kaçınması veya dikkat etmesi gereken noktalara değinmektedir ${ }^{49}$. Bunu da Quintus'un bu eserinin ilk paragrafında kullandığı “... bunlardan

43 Bunlardan bazıları için bk.: Bücheler 1869, 2 vdd.; Tyrrell 1885, 121; Syme 1939, 11 dn. 5; Syme 1947, 200; Münzer 1948, 1288; Taylor 1949, 64 vdd.; Till 1962, 316 vd.; Holliday 1969, 17; Nardo 1970, $29-55$ ve 129 vdd.; Richardson 1971, 440 vdd.; McDermott 1971, 8 vd.; Morstein-Marx 1998, 261; Tatum 1999, 256 dn. 99; Laser 2001, 4 vdd.; Dugan 2005, 1, dn. 1; Telatar - Ak 2009,127; Nótári 2010, 35 vdd.; Francese - Smith 2014, 77.

44 Bunlardan bazıları için bk. Hendrickson 1892, 211 vd.; Henderson 1950, 21 vdd.; Syme 1958, 47 vd. Syme başlangıçta (1939, 11 dn. 5) bunun Quintus tarafından kaleme alındığını düşünmekle birlikte, daha sonra (1958, 47 vd.) eserin Augustus zamanında bir başkası tarafından yazıldığını ifade etmiştir.

45 Eserin yazarının Quintus olmadığına yönelik düşünce temelde, Eussner'in 1872 yılında ileri sürdüğü görüşlerle başlamıştır. Bununla birlikte, benzer görüşleri benimseyen daha sonraki fikirlerin şekillenmesinde Hendrickson'un 1892 ve 1903 yıllarında yazdığı iki çalışması büyük rol oynamıştır. Eserin yazarına yönelik benzer fikirleri dile getiren eserler için bk. Mommsen 1887, 484 dn. 3 ve 497 dn. 3; Hendrickson 1892, 203 vdd.; Hendrickson 1903, 4 vdd; Watt 1958, 179. Eserin yazarı ve tarihi üzerine yapılan tartışmalar hakkında bk. Bailey 2002, 396 vdd.; Alexander 2009a, 33 vdd.

46 Gruen 1974, 138 dn. 76; Morstein-Marx 1998, 261; Yakobson 1999, 24 dn. 6; Alexander 2009a, 36 vd. Ayrica bk. Syme 1947, 200; Tatum 1999, 256 n. 99.

47 Laser 2001, 4 dn. 5.

48 Alexander 2009b, 389.

49 Sicilia'da 75 yılında quaestor olarak hizmette bulunan Cicero, kardeşine sürekli yaptığı bu tavsiyelerden dolayı kendisinin ona karşı bir akıl hocası gibi hareket ettiğini düşünmektedir. Cic. QFr. 1. 1. 18. Cicero'nun kardeşine yaptığı tavsiyeler ve Quintus'un yönetim anlayışı üzerine ayrıca bk. Akoğlu 2014, 9 vdd. 
yeni bir şey öğrenmen için değil de ..." ifadesinde olduğu üzere, kardeşinin bilgi ve beceri yönünden kendisinden aşağı olmadığını belirterek kardeşi gibi nezaketli bir şekilde yapmaktadır ${ }^{50}$. Cicero aslında öğüt almaktan hoşlanmayan ve sabit fikirli bir adam değildir. Kendisinin mektup yazdığı kimselere fikirlerini sorması da bunu açık bir şekilde ortaya koymaktadır. Bunun yanında Cicero'nun kardeşine yazdığı mektupların birinde, açık bir şekilde bu olayı kastetmemekle birlikte, kardeşini işaret ederek kendisine ondan başka kimsenin büyük bir isim sahibi olmasında yardımcı olmadığını belirtmektedir ${ }^{51}$. Kardeşine yazdığı bir diğer mektupta ise kardeşiyle yazışmanın kendisine verdiği mutluluğa değinmekte ve kardeşinden aldığı uzun mektupların kendisini daha fazla hoşnut ettiğini ifade etmektedir ${ }^{52}$.

Bu eserin consul olmayı zaten başarmış olan Cicero'ya kardeşi tarafından yazııması yerine, ilerleyen yıllarda başkasının ağzından yazılması çeşitli soru işaretlerini beraberinde getirmektedir. En önemli soru işaretini ise, en azından 80 yıl kadar bir sürenin ardından bir kimsenin büyük bir emek harcanmış bu eseri kendi adıyla yazmak yerine, 64 yılı ve öncesinde gerçekleşen olayları, insani ilişkileri ve o dönemde yazılmış diğer eserleri detaylı bir şekilde irdeleyerek neredeyse hiçbir kronoloji tutarsızığı olmayacak bir anlatımla consul olmayı zaten başarmış Cicero'ya kendisine çok yakın bir kimsenin ağzından seçim tavsiyesinde bulunma intiyacına gereksinim duyması yaratmaktadır $^{53}$. Eğer böyleyse Quintus'un kusursuz olmasını arzuladığı bu eserinin sonunda ağabeyine, uygun görmediği bir yer olması halinde bunu kendisine bildirmesi temennisinde bulunması, ilerleyen yıllarda bunu yazan kimse tarafından çok ince düşünülmüş bir davranış olarak gözükmektedir. Ayrıca böyle bir durumda, çok ayrıntılı ve iyi bir eser kaleme alındığı için doğal olarak kendisini tamamen edebi işlere vermiş olması gereken bir kimsenin başka eserler de yazmış olması ve bunların varlığından en azından başka eserler vasıtasıyla haberdar olunması beklenirdi. Eğer amaç eserin içeriğini oluşturan önemli etkenlerden biri olduğu gözüken, homo novus bir kimsenin karşılaştığı güçlükleri yeniden gündeme getirmek ve Roma'da bir şekilde fırsat eşitliği olduğuna veya olmadığına dair bir algıyı tekrar sağlamak gibi bir düşünce olsa bile, Augustus zamanından itibaren consul seçimlerinin statüsünün zaten farklılaşmış olduğu gözardı edilmemesi gereken bir unsurdur.

Bu eserin Cicero'nun kendisi tarafından yazılması durumunda ise, Cicero'nun, kendisinin de mensubu olduğu ve varlığına büyük önem verdiği atlı sınıfının seçimlerdeki gücünü hor görmesi kendi tutumuyla çelişmektedir. Bunun yanında optimates kesim ile karşı karşıya gelmemek için, 70 yılından itibaren büyük bir işbirliği içerisine girdiği ve birçok adamını savunduğu Pompeius ile seçim sürecinde halkçı olduğu gerekçesiyle çok içli dışlı olunmaması gerektiğinin tavsiye edilmesi ${ }^{54}$ de büyük bir çelişki oluşturmaktadır. Aynı şekilde hem seçim öncesinde hem de consul olduğu sırada kendisinden çok korkulması gerektiğ: ${ }^{55}$ düşüncesine sahip olduğu Catilina'yı bu-

50 Henüz eyalet valisi olarak bir görevde bulunmadığı halde, Cicero tarafından 60 veya 59 yılı başlarında, Asia Eyaleti valisi olan kardeşi Quintus'a eyalet yönetimi üzerine sürekli tavsiyede bulunulması bir tavsiye için illa ki o görevde bulunulmaması gerektiğine delil olarak gösterilmiştir. Tyrrell 1885, 114 vd.; Alexander 2009a, $33 \mathrm{vd}$.

51 Cic. QFr. 1. 1. 43

52 Cic. QFr. 1. 1. 45.

53 Krş. Till 1962, 316 vd.; Laser 2001, 7; Nótári 2010, 37 vdd.; Francese - Smith 2014, 77.

54 Ascon. Tog. Cand. 5.

55 Cicero (Cat. 3. 16; 3. 17) Catilina'nın öncülük ettiği darbe girişiminde onun plan yapma ve bu planları uygulama becerisine vurgu yapmış ve en fazla ondan korkulması gerektiğini belirtmiştir. Ancak 44 yılında kendisinin tekrar belirttiği gibi (Phil. 2. 118) bu korku, kendi yaşamına yönelik duyduğu şahsi bir korku olarak algılanmamalıdır. 
rada aşırı sayılabilecek düzeyde küçümsemesi ${ }^{56}$ yine kendi tutumuyla çelişmektedir.

Quintus Roma'da olduğu müddetçe zamanının büyük kısmını ağabeyi ile birlikte geçirmiştir. Ayrıca 65 yılında, kariyer sırasındaki önemli makamlardan biri olan aedilis plebis görevinde bulunmuştur. Bu nedenle söz konusu eserini büyük ölçüde, devlet kademesinde işlerin nasıl yürüdüğüne ve seçimlerin nasıl kazanıldığına yakından şahit olduğu aedilis plebis olarak görevde bulunduğu sırada edindiği tecrübeler ${ }^{57}$ ve ağabeyinin yanında bulunması sayesinde yaptığı gözlemler sayesinde yazmış olmalıdır. Kendisinin seçim kampanyasına yönelik bu eserinin kusursuz olması temennisinde bulunması da, metin üzerine çokça kafa yorduğuna ve hazırlık yaptığına işaret etmektedir. Çünkü ağabeyi kadar hırslı olmamasına karşın, Cicero'nun consul seçilmeyi başarması, kariyerinde belli bir noktaya gelen Quintus'un da olası consul adaylığı sırasında önünü açacaktı. Bu nedenle ağabeyinin consul olmayı başarması kendisi için de büyük bir önem taşımaktadır.

Commentariolum Petitionis hariç tutulursa ${ }^{58}$, aktarımlar ve veriler Quintus'un asıl marifetinin ve faaliyetinin şiir sanatında olduğunu göstermektedir. Quintus'un yazım çalışmaları hakkında bir fikir edinilmesini sağlayan ağabeyi de, onu bu uğraşta kendisinden daha başarılı bulmuştur. Quintus'un şiir çalışmalarına yönelik ilk veri 66 yılına ait olan bir epigramdır ve bu epigramın varlığı, sürgünde olan Cicero'nun içinde bulundukları zor durumda kimlerden yardım istenebileceğine dair tespitler içeren bir mektubu sayesinde bilinmektedir ${ }^{59}$. Cicero kardeşine yazdığı bu mektupta ondan, 66 yılında aediles adayı olduğu sırada, mahkemelerdeki jüri dağıımını düzenleyen lex Aurelia düzenlemesine ${ }^{60}$ yönelik tavrını ortaya koyan epigramı bilen Hortensius ile arasını düzeltmesini istemiştir. Epigramın kimi hedef aldığı açık değildir ${ }^{61}$. Buna karşın Quintus'un 64 yılındaki Commentariolum Petitionis isimli eserinde consul adayı olan ağabeyine, optimates kesimi karşısına almamak adına halkçı olan Pompeius ile seçim sürecinde çok içli dışlı olmaması gerektiğini tavsiye etmesi ${ }^{62}$ göz önüne alındığında, bu epigram ile, yasanın çıkmasına destek veren Pompeius'u hedef alması daha olasıdır. Ancak bu epigram her halükarda,

57 Kendisinin edindiği deneyimlere dair değerlendirmeler için ayrıca bk. McDermott 1971, 713 vdd.

58 Ağabeyi pek tasvip etmemekle birlikte, kendisinin düzyazıda da keskin ve iğneleyici bir üslubunun olduğu anlaşılmaktadır. Bk. Cic. QFr. 1. 2. 6-7.

59 Cic. QFr. 1. 3. 8. Bu epigram, sürgünde olan Cicero'nun kardeşi Quintus'a 13 Haziran 58 tarihinde yazdığı bir mektup sayesinde bilinmektedir.

60 L. Aurelius Cotta 70 yılında praetor olduğu sırada yürürlüğe soktuğu bir düzenleme uyarınca, mahkemelerdeki jüri üyelerinin tekrar equites sınıfı, tribuni aerarii ve senatus mensupları arasından seçilmesini sağlamıştı. Düzenleme Pompeius ile Crassus consul iken gerçekleştiği ve senatusun yetkilerini kısıtladığı için, bu düzenlemenin arkasında doğal olarak başta Pompeius olmak üzere iki consul bulunmaktaydı.

61 Bir kısım bilim insanı (Bailey 2002, 72 dn. 11; 2004, 168; Walsh 2008, 294), bu epigramın yeni yasanın çıkarılmasında desteği olan Pompeius ile Crassus'u hedef aldığını Hortensius'un bildiğini düşünmektedir. Buna bağlı olarak da Cicero, yasaya karşıt bir düşünce sergileyen bu epigramın kendisinin sürgünden dönmesi adına Pompeius nezdinde girişimlerde bulunan kardeşine karşı Hortensius'un kullanacak olmasından dolayı endişelenmiş ve ondan böyle bir istemde bulunmuştur. Bazıları ise (Stinchcomb 1932, 5; Marshall 1975, 136), yasaya yönelik olumlu bakışı nedeniyle Cicero'nun, kardeşinin keskin diliyle Hortensius ile muhafazakâr kesimi rahatsız edecek olmasından ve bunun da sürgünde olan kendisinin durumunu zora sokacak olmasından dolayı endişe taşıdığı şeklinde yorumlamışlardır.

62 Q. Cic. Comm. Pet 5. Ayrıca bk. Q. Cic. Comm. Pet. 14; 51. Quintus, iç savaşı Pompeius'un kaybetmesinin ardından kendisini Caesar'a affettirmek için, Pompeius safında yer almasının tamamen ağabeyinden kaynaklandığını iddia etmiş ve onu suçlamıştır. Oğluyla birlikte hareket eden Quintus ile Cicero'nun arasının bozulma süreci üzerine bk. Cic. Att. 11. 5; 11. 6. 7; 11. 7; 11. 8; 11. 9; 11. 10; 11. 12; 11. 13; 11. 15; 11. 16; 11. $20 ; 11.22$ 
Quintus'un gençlik döneminden itibaren şiir sanatına gönül verdiğine yönelik bir belirti sunması açısından önemlidir. Görünüşe göre Asia Eyaleti'ndeki valilik görevinin uzatılmasından duyduğu rahatsızlık nedeniyle, sıkıntısından uzaklaşmak için başladığı Annales ${ }^{63}$ isimli çalışmasını ve görevde bulunması vesilesiyle gördüğü Britannia'nın farklı ve korkutucu doğasına yönelik eserini nazım türünde düzenlemesi de düz yazıdan ziyade şiire ilgi duyduğunu ve bu uğraşta oldukça iddialı olduğunu ortaya koymaktadır. Kendisinin antik dönemde epik ve tragedya yazarı olarak tanımlanması da ${ }^{64}$ bunu doğrular niteliktedir.

Quintus'un şiirleri çoğunlukla Gallia ve Britannia'da bulunduğu zamana aittir ${ }^{65}$. Bununla birlikte bunların hiçbiri günümüze kalmamıştır ve bunlar ağabeyine yazdığı mektuplara ağabeyinin verdiği cevaplar sayesinde bilinmektedir. 54 yılının Temmuz ayı sonlarında Britannia'da olduğu bilinen Quintus ${ }^{66}$ büyük bir hayranlık duyduğu ve eserlerini temellendirdiği ${ }^{67}$ Sophokles'in $\sigma u ́ v \delta \varepsilon \iota \pi v o \iota^{68}$ isimli yergi türündeki eserini Latince'ye uyarlamış ve Ağustos ayı sonlarında kurye aracılığıyla bunu ağabeyinin değerlendirmesine sunmuştur ${ }^{69}$. Cicero kardeşine eğlenceli hoş bir çalışma yapmış olduğunu dile getirmekle birlikte, içeriğinden dolayı Sophokles'in bu eserini pek tasvip etmediğini bildirmiştir ${ }^{70}$. Gerek Cicero'nun bu ifadesi, gerekse de eserin başlığı çalışmanın özgün bir eser olmadığını ortaya koymaktadır. Yine bu mektuptan, Caesar tarafından yapılan fetih hareketleri yoluyla Romalıların yeni tanımaya başladığı Britannia'nın coğrafyası ile kültürünü yansıtan bir eser yazmayı tasarladığı öğrenilmektedir ${ }^{71}$. iki kardeşin $^{72}$ bu sıralardaki yaklaşımı nedeniyle, bu çalışma doğal olarak Caesar'ın orada elde ettiği başarıları da içermektedir. Zamanını çoğunlukla Gallia'da geçiren Quintus'un, sadece Britannia üzerine eser yazma ihtiyacı hissetmesi, Britannia'nın farklı bir coğrafi yapıya sahip olmasından ve bölgenin yeni tanınmasına bağlı olarak o sıralarda Romalı yazarlarca popüler olması nedeniyle kendisinin de ilgisini çekmiş olmasından kaynaklanmış olmalıdır. Romalıların ilk kez Caesar komutasında ayak bastıkları Britannia'nın doğası ve coğrafyası için kendisinin böyle bir eser yazması haliyle, burada elde edilen başarılarda önemli bir pozisyona sahip olan kendisine de hem yazar hem de idareci olarak kalıcı bir ün sağlayacaktır ${ }^{73}$. Doğası ve yapısı kendisini ürkütmesine karşın bölge, Caesar ile

63 Cicero 59 yılının Mayıs ayı başlarında Atticus’a yazdığı bir mektupta kardeşinin bu eserini düzeltilmesi ve yayınlanması için kendisine istekte bulunduğu bilgisini vermiştir. Bk. Cic. Att. 2. 16. 4. Ayrıca bk. QFr. 1. 1. 44.

64 Schol. Bob. 60: Fuit enim Q. Tullius non solum epici, verum etiam tragici carminis scriptor. Kendisinin mektup yazmada sergilediği ustalık da takdir edilmektedir. Bk. Cic. QFr. 3. 1. 22.

65 Quintus'un Asia Eyaleti'ndeki görevi sırasında Annales isimli eserine başlayıp belli bir noktaya getirmesi ve Britannia'da olduğu sırada çok sayıda edebi çalışmaya girişmesi, kendisinin Roma dışında görev yaptığı zamanlarda da yanına birçok kitap götürdüğüne işaret etmektedir. Ayrıca her zaman yeni kitaplar temin etmek için uğraş veren kendisinin normalde de iyi bir kütüphaneye sahip olduğu anlaşılmaktadır. Cic. QFr. 3. 4. 5; 3. 5. 6-7; Att. 2. 3. 4; 13.8.

66 Cic. Att. 4. 15. 10.

67 Cic. Fin. 5.3.

68 Söz konusu bu eser Sofradaşlar olarak çevrilebilir.

69 Kendisinin edebi faaliyetleri ve ağabeyinin eserlerindeki varlığı üzerine bk. McDermott 1971, 703 vdd. Quintus aynı zamanda, Roma dışında idari görevlerde bulunduğu sırada, ağabeyinin eserlerini yakından takip etmiş ve ondan çalışmaları konusunda sürekli bilgi almıştır. Ağabeyi de ona yazdıklarını okuyup değerlendirmesi için göndermiştir. Bk. Cic. QFr. 2. 8. 1; 3. 1. 11; 3. 5. 1.

70 Cic. QFr. 2. 16. 3.

71 Cic. QFr. 2. 16. 4. Ayrica bk. Allen 1955, 143 vdd.; Kruschwitz 2014, 276 vdd.

72 Bu mektup sayesinde ayrıca Quintus, ilişkilerde yeni bir evrenin başladığı Caesar ve Cicero üçgeninde bir şiir yazma adetinin oluştuğu anlaşılmaktadır.

7314 Şubat 54 tarihli mektuptan (Cic. QFr. 2. 12. 4) öğrenildiğine göre, Quintus daha henüz Gallia'daki görevine başlamadan, muhtemelen görev alacağı yerlere ilişkin bir tarih yazımına yönelme düşüncesindedir 
ilişkisini güçlendirmek isteyen Cicero'nun ${ }^{74}$ da ilgisini çekmiştir ${ }^{75}$. Bu nedenle Quintus, nazım türünde yazmayı planladığı bu eserinde, ağabeyinden bazı dizeler yazması temennisinde bulunmuştur. O sıralardaki savunmalar nedeniyle neredeyse başını kaldıracak fırsatı olmayan Cicero sadece düzenleyici olarak katkı sağlamak niyetinde olmakla birlikte, yine de Eylül ayında kardeşine fırsat bulması durumunda istediklerini yazacağını belirtmiştir ${ }^{76}$. Ancak 54 yılının Ekim ayı sonlarında kardeşine yazdığı diğer mektuplarda ${ }^{77}$ ise hem boş vakte hem de kaygıdan uzak dinginlik isteyen ilhama sahip olmadığını ve bu noktada onun kendisinden daha iyi olduğunu da ifade ederek bunu yapamayacağını bildirmiştir ${ }^{78}$. Bu konuda muhtemelen ağabeyinden de gereken desteği ve teşviği görememesi nedeniyle çalışmasını bitirememiş gözükmektedir.

Ağabeyi yoğunluktan ve endişeden uzak olmadığı gerekçesiyle şiir yazmaktan uzak dururken, kendisinin bu yönde faaliyetlerde bulunması Quintus'un şiiri bir ölçüde ailesinden, ağabeyinden ve Roma'dan uzakta olduğu zamanlarda onların boşluğunu doldurmak ve tehlikeli görevinden kaynaklanan stresten uzaklaşmak için bir araç olarak gördüğü düşünülebilir. Nitekim, zamanının önemli bir bölümünü yerel halkla savaşarak geçirmesine karşın, fırsat bulduğu sırada bir şeyler yazan veya çeviren Quintus'un bir diğer uğraşı Sophokles'in tragedyasının Latince'ye uyarlanmış hali veya başka türde bir şiir çalışması olan Erigonadır. Bunun varlığına yönelik bilgiler de bir mektup yoluyla bilinmektedir. Quintus çalışmasını, Britannia'da yürütülen savaş sırasında, muhtemelen eserini tamamlamasının hemen ardından ağabeyinin fikrini sormak amacıyla kurye vasıtasıyla 10 Ağustos 54 tarihinde göndermiştir. Ancak bu eser ne yazık ki Cicero'ya ulaşmamıştır. Cicero eline geçmesi durumunda, bunu okuyacağına ve bunu beğeneceğinden şüphe etmeyeceğine dair bir cevap yazmasına karşın sonraki zamanlarda da ${ }^{79}$, esere dair hiçbir veri yoktur. Asker olduğu için fazlasıyla iş yükü ve sorumlulukları olması gereken kardeşi Ekim ayında da, 16 gün içinde dört tane tragedya yazmıştır. Cicero bu durumda şaşkınlığını gizleyememiş ${ }^{80}$ ve bunu şaka olarak başkasından kendisine mal ettiğini varsaydığını belirtmiştir ${ }^{81}$. Bunların ikisinin Electra ${ }^{82}$ ve Troades isimli çalışmalar olduğu bilinmektedir ${ }^{83}$. Aynı isimde Yunan edebiyatında da eserler

ve ağabeyi de kendisini bu konuda yüreklendirmiştir.

Caesar ile ilişkileri güçlendirmek adına Cicero (QFr. 3. 6. 3. Krş. 2. 14. 2) kardeşinin teşvik etmesiyle Caesar'a ithafen bir şiir de yazmaya koyulmuştur. Cicero (QFr. 3. 1. 11) 54 yılının Eylül ayında Britannia'da bulunan kardeşine yazdığı uzun mektupta Caesar için kaleme aldığı şiiri bıraktığını belirtirken, Aralık ayında (QFr. 3. 7. 6) kardeşinin Caesar için teşvik ettiği epik şiiri bitirdiğini ve güvenilir bir kurye bulması durumunda bunu göndereceğini belirtmiştir. Görünüşe göre bu eser, üç kitaptan oluşan de Temporibus Meis başııkı çalışmasının bir bölümünüdür. Bk. Cic. Fam. 1. 9. 23.

75 Quintus ağabeyini bu konuda da teşvik etmiş ve görünüşe göre Britannia'nın doğası ve gelenek görenekleri gibi ona ihtiyacı olan bilgileri sunmuştur. Cic. QFr. 2. 14. 2.

76 Cic. QFr. 3. 1. 11.

77 Cic. QFr. 3. 4. 4; 3. 5.4

78 Buna karşın Cicero, Caesar için hazırladığı epik şiiri bitirmiştir. Cic. QFr. 3. 7. 6; Fam. 1. 9. 23.

79 Sophokles'in günümüze kalmayan eserlerinden biri olan Erigone isimli eserinin Latince'ye bir uyarlaması olan çalışmanın varlığına dair bk. Cic. QFr. 3. 1. 13; 3. 5. 7; 3. 7. 6. Ayrıca bk. Bailey 2002, 155 dn. 14.

80 Ancak Cicero'nun da bir gecede beş yüz dize yazdığı rivayet edilmektedir. Bk. Plut. Cic. 40. 3.

81 Cic. QFr. 3. 5. 7. Buna karşın Cicero (Div. 1. 32) kardeşinin nazım türünde oldukça başarılı olduğunu belirtmiştir. Değerlendirmeler üzerine ayrıca bk. Ribbeck 1875, 624 vd. Quintus'un çok yakın bir dostluk sergilediği Tiro'ya tavsiyelerde bulunurken Euripides'ten alıntı yapması da (Cic. Fam. 16. 8. 2) Yunan tragedyasına duyduğu büyük ilgiyi ve Yunan edebiyatına olan hakimiyetini ortaya koymaktadır.

82 Cicero 45 yilında (Fin. 1. 2. 5) Sophokles'in Electra isimli eserini tercüme eden kişi olarak sadece Atilius'u anmaktadır. Bu nedenle Quintus'un yapmış olduğu çeviri veya uyarlamanın Euripides veya başka bir yazara ait olabileceği düşünülmektedir. Bk. Ribbeck 1875, 619.

83 Bailey $(2002,187$ dn. 7) genel olarak Troades olarak bilinen bu eserin Sophokles'in kayıp çalışmalarından 
olduğu ve bunları çok kısa bir süre içinde tamamladığına bakılırsa, bu çalışmalar da özgün eserler yerine çeviri çalışmaları olmalıdır.

Quintus'un önemli ve günümüze kalan nadir çalışmasından birisi, MS. IV. yüzyılda yaşamış olan Ausonius'un Eclogues isimli eseri içerisinde yer bulması sayesinde bilinmektedir. 20 satırı ele geçen ve heksametron vezninde yazılmış olan bu eseri öğretici bir şiirdir ${ }^{84}$. Latin edebiyatında Cicero'nun 87 veya 86 yıllarında Aratus'un Phaenomena adlı eserinden çeviri yoluyla oluşturduğu Aratea isimli çalışmasında ${ }^{85}$ ele almasından sonra sıkça irdelenmeye başlayan burçlar hakkında olan bu çalışmanın tarihi kesin değildir ${ }^{86}$. Ayrıca Ausonius, burçları on iki bölüme ayıran bu metnin Quintus'a ait olduğunu belirtmesine karşın, Commentariolum Petitionis isimli çalışmada olduğu gibi bunun da aidiyetliği sorgulanmış ve Cicero'nun eserlerinde de benzer ifadeler bulunması nedeniyle bunun ağabeyi veya başkası tarafından yazılmış olabileceği ileri sürülmüştür ${ }^{87}$. Yine kendisine ait olup olmadığı tartışmalı olan ve kadınlara güvenilmemesi gerektiğini dile getiren bir dörtlüğü daha günümüze kalmıştır ${ }^{88}$.

Her ne kadar sadece iletişim kurma ve bilgi edinme aracı olarak kullanılsa da, Quintus Tullius'un şiirler dışındaki yazım faaliyetinin büyük kısmını mektupların oluşturduğu anlaşılmaktadır. Zaten kendisi görevi gereği birçok kez ailesinden uzakta olduğu için, hem ailesiyle ilgilenen hem de Roma'da olup bitenleri haber veren ağabeyiyle sağlıkı bir iletişim kurmasını sağlayacak başka bir yol bulunmamaktadır. Bunun tersi bir durum Cicero'nun on altı ay kadar bir süre sürgünde bulunduğu sırada gerçekleşmiş ve kendisinin sürgünden dönmesi için var gücüyle çalışan kardeşi hem onun şahsi sorunlarıyla yakından ilgilenmiş hem de ona kendisini ilgilendiren gelişmeler konusunda bilgi vermiştir. Kendilerinde büyük bir hayal kırıkığı yaratan iç savaş sonrasında birbirlerine çok düşmanca bir tutum sergiledikleri dönem hariç tutulursa, Quintus'un can ciğer diye tabir ettiği ağabeyiyle çok düzenli bir şekilde mektuplaştığının en açık kanıtını Cicero'nun Quintus'a yazdığı 27 mektup ortaya koymaktadır ${ }^{89}$. Quintus'un Asia Eyaleti'nde propraetor olarak bulunduğu görevinde daha fazla kalmak istemediği halde ${ }^{90}$, görev süresinin

olan Troilus veya Procris olabileceğini belirtmektedir. Quintus'un Electra ve Troades isimli eserleri üzerine ayrıca bk. Kruschwitz 2014, 287 vd.

84 Stinchcomb 1932, 5; Green 1991, 705 vd.; Possanza 1992, 44 vdd.; Courtney 2003, 189 vdd.; Gee 2007, 565 vdd. Decimus Magnus Ausonius için ayrıca bk. Kurul - Yılmaz 2018, 559 vdd.

85 Cic. nat. D. 2. 104. Ayrıca bk. Menzilcioğlu 2012, 468 dn. 221 ve 222. Cicero bu konuyu 45 ve 44 yıllarında yazdığı Tusculanae Disputationes (1.68) isimli çalışmasında da ele almıştır.

86 Eserin Quintus'a ait olduğunu düşünen Possanza $(1992,46)$ bunun 58 ile 46 yılları arasında yazıldığını düşünmekle birlikte, Gee (2007) bunun Quintus'a ait olduğunu kabul etmediği için net bir tarih aralığı vermekten kaçınmaktadır.

87 Gee 2007, 581 vdd.

88 Bücheler 1869, 25 vdd.; Green 1991; 705 vd.; Courtney 2003, 179 vdd. Stinchcomb (1932, 5) dörtlüğün Quintus'a ait olması durumunda, kadınlara hakareti içermesinden dolayı bunun kendi eşi Pomponia ile yaşadığı anlaşmazlık nedeniyle ondan boşanmasının ardından yazıımış olabileceğini düşünmektedir. Esasen, eşiyle yaşadığı sorunlar ve abisinin uyarıları da, bu dörtlüğün Quintus'a ait olabileceğine işaret etmektedir.

89 Birinci kitabı teşkil eden uzun ilk iki mektup Quintus Asia Eyaleti'nde olduğu sırada yazılırken, bu kitap içerisinde yer verilen diğer iki mektup Cicero sürgünde iken yazılmıştır. 16 mektuptan oluşan ikinci kitabın ilk 6 mektubu da Quintus'un Pompeius komutasında tahıl temini işiyle görevlendirildiği sırada yazılmıştır. 15 Mayıs 56 ile 54 yılının Mayıs ayları arasına tarihlenen 7. mektubu ile 13. mektubu arasında herhangi bir görevde bulunduğu bilinmemekle birlikte, diğer mektupları yazıldığı sırada bu kez Caesar idaresinde Gallia ile Britannia'da görev yapmıştır. Aynı şekilde, üçüncü kitabını oluşturan ve 54 yılı sonlarına kadar olan süre zarfında yazılan 7 mektup da Caesar ile görev yaptığı sırada yazılmıştır. Mektuplar ve bunların tarihleri üzerine bk. Bailey 2002.

90 Değerlendirmeler üzerine bk. Brennan 2000, 567. 
uzatıldığı 60 yılı sonlarından itibaren başlayan bu mektuplaşma 54 yılı biterken sona ermiştir ${ }^{91}$. Bu mektuplar genel olarak Quintus'un ağabeyine veya ağabeyinin Quintus'a sorduğu sorulara yanıtlar ve destek mesajları içerdiğinden kardeşinin de en azından bu mektuplar kadar mektubu olması gerekmekle birlikte, bunlar ne yazık ki ele geçmemiştir ${ }^{92}$.

Quintus'un günümüzde sadece dört mektubu bilinmektedir. Bunlardan birisi ağabeyine ${ }^{93}$ diğerleri ise azat edilmiş Tiro'ya yazıımışıı ${ }^{94}$. Ağabeyine 53 yılııın Mayıs ayı sonlarında veya Haziran ayı başlarında yazdığı mektubunda, ağabeyinin eserlerinin yazımı sırasında çok büyük bir yardımcısı olan Tiro'yu azat etmesine duyduğu memnuniyeti dile getirmiştir ${ }^{95}$. Quintus'un bir köleden ziyade dost olarak gördüğü Tiro'ya yönelik samimi ve dostane hislerini kendisinin yazdığı mektuplar da açık bir şekilde göstermektedir. Cicero'nun Cilicia Eyaleti'ndeki görevi sırasında beraberinde götürdüğü Tiro'yu rahatsızlık geçirmesi nedeniyle onu Patrae'da bırakmasına karşın onun sağlığına yönelik Quintus'un duyduğu endişeyi taşıyan, kendine dikkat etmesi ve neler yapması gerektiğini tavsiye eden dostane mektubu bunun açık bir örneğidir ${ }^{96}$. Tarihi tam belli olmayan bir diğer mektubunda" ${ }^{97}$ Quintus, büyük güven duyduğu ve çok sevdiği Tiro'dan mektupsuz bir paket gelmesi üzerine ona sitem etmiş ve onun kendisini ancak mektup yazarak affettirebileceğini bildiren bir mektup yazmıştır. Bilinen üçüncü mektup da ona duyduğu güveni yansıtmakta ve aralarındaki dostluk ilişkisinin çok güçlü olduğunu göstermektedir ${ }^{98}$.

\section{Sonuç}

Ağabeyinin mektuplarında değinmesi sayesinde, bazı eserlerin kesin olarak Quintus'a ait olduğu öğrenilirken, ağabeyinin kendisine atıfta bulunmaması durumunda eserleri başta ağabeyi olmak üzere diğer yazarlara atfedilmiştir. Günümüze ulaşan çalışmalarının aidiyetliği üzerinde bilim dünyasında genel bir mutabakat olmamasının temelinde kendisinin üretken bir yazar olmaması yanında çok büyük bir yazar ve hatip olan ağabeyine yakın yaşlarda olması ve hayatını çoğunlukla onunla birlikte geçirmesi yatmaktadır. Çünkü birbirleriyle sıkı fıkı oldukları ve yazdıklarını birbirlerine değerlendirme amacıyla gönderdikleri için, yazımlarında benzer ifade şeklinin görülmesi son derece olağan olmakla birlikte, Cicero kardeşinin yazımına yönelik bir değerlendirmede bulunmamışsa veya onun çalışmasına değinmemişse zaten çok az sayıda olan mevcut eserleri

91 Quintus, Caesar komutasında 52 yılı sonlarına kadar bölgede kaldığı ve ağabeyiyle aralarında bir sorunun varlığı bilinmediği için, mektuplaşma doğal olarak devam etmiş olmalıdır.

92 Cicero'nun eserleri ve veriler Quintus'un oğlu, kayın biraderi Atticus, yakın dostu Tiro ve başkaları ile düzenli bir şekilde mektuplaştığına ve çok sayıda mektubun varlığına işaret etmekle birlikte (Cic. Att. 1. 17; Fam. 16. 26; QF. 1. 1. 26; 3. 1. 13; 3. 1. 19) Tiro'ya yazılan 3 mektup haricinde hiçbir şey ele geçmemiştir. Quintus'un yakınlarıyla düzenli şekilde mektuplaştığına dair ayrıca bk. Stinchcomb 1932, 4 vd.

9353 yılının Mayıs sonlarına veya Haziran ayı başlarına ait olan bu mektubu için bk. Cic. Fam. 16. 16. Ağabeyine ve Tiro'ya yazılan mektupların ağabeyi tarafından kendisine yazılan mektuplar içerisinde yer almaması da kendisinin çok daha fazla mektubunun olduğuna işaret etmektedir.

94 Muhtemelen 49 yılının Ocak ayına ait olan diğer mektubu için bk. Cic. Fam. 16. 8. Tarihi belli olmayan mektubu için bk. Cic. Fam. 16. 26. 44 yılının sonlarında yazılan bir diğer mektubu için bk. Cic. Fam. 16. 27.

95 Tiro'nun azat edilme zamanı üzerine bk. McDermott 1972, 260 vdd.

96 Cic. Fam. 16. 8. Tiro bundan bir süre önce Cicero'dan da sağlığı hakkında iyi niyet temennileri içeren çok sayıda mektup almıştır. Bunlarda diğer aile üyeleri yanında, Quintus'un da iyi niyet temennileri bulunmaktadır. Mektuplar için bk. Cic. Fam. 16. 1 - 16. 7; 16. 9; 16. 11; 16. 12. Cicero'nun Tiro için duyduğu endişeler üzerine ayrıca bk. Cic. Att. 7. 2. 3; 7. 3. 12; 7. 5. 2; 8. 6. 5; 9. 17. 2; 10. 4. 12. Değerlendirmeler üzerine bk. McDermott 1972, $261 \mathrm{vd.}$

97 Bailey (2001, 169 dn. 1) genel olarak 44 yılına tarihlenen (Stinchcomb 1932, 4) bu mektubun çok daha önceki bir tarihte, muhtemelen de Quintus'un Gallia'da görev yaptığı sırada yazılmış olabileceğini düşünmektedir.

98 Cic. Fam. 16. 27. Tiro'nun kendisine mektup yazmasına dair isteği üzerine ayrıca bk. Cic. QFr. 3. 1. 10. 
yazım yönünden daha kuvvetli olan ağabeyine veya başka yazarlara atfedilmiştir. Şiire büyük bir ilgi duyan Quintus'un bu alandaki yeteneğini ağabeyi övmesine ve onun şiirde kendisinden daha başarılı olduğunu ifade etmesine karşın, Cicero vasıtasıyla bilinen çalışmalarının çoğunlukla ünlü Yunan yazarlara ait eserlerin başlıklarını taşıması ve bunların ele geçmemiş olması bu algının oluşmasına ve özgün olabilecek eserlerinin sorgulanmasına yol açmıştır.

Aslında, idari ve askeri görevleri nedeniyle rahat bir ortamda olmadığı halde, 66 yıındaki epigramı haricinde, şiirlerinin Roma dışında idari görevde olduğu zamanlara yani ağabeyinden uzakta olduğu zamanlara ait olması Quintus'un kendi hayatını ağabeyinin başarısına adadığına ve kendisinin, yazım açısından onun yanındayken verimli bir zaman geçiremediğine işaret etmektedir. Bunun yanında aedilis olmak için adaylığını koyduğu sırada yazdığı bir epigramın ağabeyinde yarattığı korkudan da anlaşılacağı üzere, ağabeyinin ileri gelenlerle kurduğu ilişki nedeniyle, insanları başarı gösterdiği alan olan şiirde sivri diliyle rahat bir şekilde hedef alamaması kendine özgü bir stil yaratmasının ve kendisini bu alanlarda geliştirmesinin önüne geçmiş olabilir. Üretken bir yazar olmamasının bir diğer olası nedeni, ağabeyinin, eşine karşı davranışlarını uyarmasından ve Asia Eyaleti'nde vali olarak görev yaptığı sırada sakinliğini koruması tavsiyesinde bulunmasından hareketle, fevri bir yapısının olması ve davranışlarında tutarsız bir görüntü çizmesi gösterilebilir. Bazı çalışmalarının tasarı düzeyinde kalması veya bitirilememesi ve genel olarak çeviri veya uyarlama olarak nitelendirilebilecek çalışmalara yönelmesi de bundan kaynaklanmış olabilir.

\section{BİBLIYOGRAFYA}

Antik Kaynaklar

App. civ.

(= Appianus, Bella Civilia) Kullanılan Metin ve Çeviri: Appian's Roman History, vols. I-IV. Trans. H. White. Cambridge - London 1912-1913 (The Loeb Classical Library).

Ascon. Tog.Cand. (= Q. Asconius Pedianus, Orationum Ciceronis Quinque Enarratio, in Toga Candida contra C. Antonium et L. Catilinam Competitores) Kullanılan Metin: Q. Asconii Pediani Oratium Ciceronis Quinque Enarratio. Ed. A. C. Clark. Oxford 1907.

Cass. Dio (= Cassius Dio, Rhomaika) Kullanılan Metin ve Çeviri: Roman History. Trans. R. Gardner. London 1914-1927 (The Loeb Classical Library).

Cic. Arch. (= Cicero, pro A. Licinio Archia Poeta Oratio) Kullanılan Metin ve Çeviriler: Oratio pro Archia Poeta. Trans. N. H. Watts. London, New York 1923 (The Loeb Classical Library). Cicero: Şair Archias Savunması. Çev. B. Demiriş - Ç. Dürüşken. İstanbul 1997.

Cic. Att.

(= Marcus Tullius Cicero, Epistulae ad Atticum) Kullanılan Metin ve Çeviri: Letters to Atticus I-IV. Trans. D. R. Schackleton Bailey. Cambridge - London 1999 (The Loeb Classical Library).

Cic. Cael. (= Cicero, pro Marco Caelio) Kullanılan Metin ve Çeviri: Cicero, pro Marco Caelio. Ed. A. R. Dyck. Cambridge - New York 2013. Marcus Tullius Cicero: Caelius Savunması. Çev. S. Gür - Kalaycıoğulları. Ankara 2016.

Cic. div. (= Cicero, de Divinatione ad M. Brutum) Kullanılan Metin ve Çeviri: De Divinatione ad M. Brutum. Trans. W. A Falconer. London - New York 1964 (The Loeb Classical Library).

Cic. Dom. (= Marcus Tullius Cicero, Oratio de Domo Sua) Kullanılan Metin ve Çeviri: The Speech Concerning the Response of the Soothsayers. Trans. N. H. Watts. London - New York 1923 (Loeb Classical Library). 
Cic. leg.

Cic. Fam.

Cic. fin

Cic. Mil.

Cic. Nat. D.

Cic. Phil.

Cic. Pis.

Cic. $Q F r$.

Cic. Red. Quir.

Cic. Scaur.

Cic. Red. Sen

Cic. Sest

Cic. Tusc.

Oros. hist.

Plut. Cic
(= Cicero, de Legibus) Kullanılan Metin ve Çeviriler: Laws. Trans. C. W. Keyes. Cambridge - London 2001 (The Loeb Classical Library). Cicero, de Legibus: Yasalar Üzerine. Çev. C. C. Çevik. İstanbul 2017.

(= Marcus Tullius Cicero, Epistulae ad Familiares) Kullanılan Metin ve Çeviri: Cicero, Letters to Friends I-III. Trans. D. H. Shackleton Bailey. Cambridge - London 2001 (The Loeb Classical Library).

(= Cicero, De Finibus Bonorum et Malorum) Kullanılan Metin ve Çeviri: De Finibus Bonorum et Malorum. Trans. H. Rackham. London - Massachussets 1967 (The Loeb Classical Library).

(= Marcus Tullius Cicero, Oratio pro T. Annio Milone Oratio) Kullanılan Metin ve Çeviriler: The Speech on Behalf of Titus Annius Milo. Trans. N. H. Watts. London New York 1992 (The Loeb Classical Library). M. Tullius Cicero Milo Savunması, Quintus Asconius Pedianus'un Yorumlarıyla. Çev. Ç. Aşkit. Ankara 2016.

(= Cicero, de Natura Deorum) Kullanılan Metin ve Çeviriler: De Natura Deorum. Trans. H. Rackham. London - New York 1972 (The Loeb Classical Library). Cicero: De Natura Deorum, Tanrıların Doğası. Çev. Ç. Menzilcioğlu. İstanbul 2012.

(= Marcus Tullius Cicero, Orationes Philippicae in M. Antonium) Kullanılan Metin ve Çeviri: The Philippics of Cicero. Trans. W. C. Ker. London - New York 1926 (The Loeb Classical Library). Philippicae Söylevleri I (1-6. Kitaplar). Çev. F. G. Özaktürk. Ankara 1998.

(= Marcus Tullius Cicero, In L. Calpurnium Pisonem Oratio) Kullanılan Metin ve Çeviri: The Speech Against Lucius Calpurnius Piso. Trans. N. H. Watts. London New York 1931 (The Loeb Classical Library).

(= Marcus Tullius Cicero, Epistulae ad Quintum Fratrem) Kullanılan Metin ve Çeviri: Cicero, Letters to Quintus and Brutus, Letter Fragments, Letter to Octavian, Invectives, Handbook of Electioneering. Trans. D. R. Schackleton Bailey. London 2002 (The Loeb Classical Library).

(= Marcus Tullius Cicero, Post Reditum ad Quirites Oratio) Kullanılan Metin ve Çeviriler: Post Reditum ad Quirites Oratio. Trans. N. H. Watts. London - New York 1923 (The Loeb Classical Library). "Post Reditum in Senatu ve Post Reditum Ad Quirites Söylevleri”. Çev. Ü. F. Telatar, S. Gür, T. Erdoğan - C. Koyuncu. Belleten 271 (2010) 871-903.

(= Cicero, pro M. Aemilio Scauro) Kullanılan Metin ve Çeviri: The Speech on Behalf of Marcus Aemilius Scaurus. Trans. N. H. Watts. London, New York 1931 (The Loeb Classical Library).

(= Marcus Tullius Cicero, Post Reditum in Senatu Oratio) Kullanılan Metin ve Çeviriler: Post Reditum in Senatu. Trans. N. H. Watts. London - New York 1923 (The Loeb Classical Library). "Post Reditum in Senatu ve Post Reditum Ad Quirites Söylevleri". Çev. Ü. F. Telatar, S. Gür, T. Erdoğan - C. Koyuncu. Belleten 271 (2010) 871-903.

(= Marcus Tullius Cicero, Oratio pro P. Sestio) Kullanılan Metin ve Çeviri: The Speeches, pro Sestio and in Vatinium. Trans. R. Gardner. London - New York 1968 (The Loeb Classical Library).

(= Cicero, Tusculanarum Disputationum) Kullanılan Metin ve Çeviriler: Tusculan Disputations. Trans. J. E. King. Cambridge, Mass.-London 1971 (The Loeb Classical Library). Cicero, Ölüme Övgü. Çev. C. Aksoy. İstanbul 2004.

(= Orosius, Historiarum Adversus Paganos Libri VII) Kullanılan Metin ve Çeviri: Seven Books of History Against the Pagans. Trans. \& Intr. I. W. Raymond. New York 1936.

(= Plutarkhos, Bioi Paralleloi: Cicero) Kullanılan Metin ve Çeviri: Plutarch's Lives. Trans. B. Perrin. London - New York 1959 (The Loeb Classical Library). Demosthenes \& Cicero, Paralel Hayatlar. Çev. İ. Çokona. İstanbul 2013. 
Plut. Pomp.

Q. Cic. Comm. Pet.

Suet. lul.

\section{Modern Literatür}

Akoğlu 2014

Alexander 2009a

Alexander 2009b

Allen 1955

Bailey 2001

Bailey 2002

Bailey 2004

Balsdon 1963

Brennan 2000

Bücheler 1869

Courtney 2003

Crawford 1984

Dugan 2005

Eussner 1872

Francese - Smith 2014

Gee 2007

Green 1991

Gruen 1974

Henderson 1950

Hendrickson 1892

Hendrickson 1903

Holliday 1969

\section{Mehmet OKTAN}

(= Plutarkhos, Bioi Paralleloi: Pompeius) Kullanılan Metin ve Çeviri: Plutarch's Lives. Trans. B. Perrin. London - New York 1959 (The Loeb Classical Library). Plutarkhos, Bioi Paralleloi, Agesilaos \& Pompeius: Giriş, Değerlendirme ve Açıklayıcı Notlar. Çev. N. Tüner-Önen. Antalya 2015.

(= Quintus Cicero, Commentariolum Petitionis) Kullanılan Metin ve Çeviri: Cicero, Letters to Quintus and Brutus, Letter Fragments, Letter to Octavian, Invectives, Handbook of Electioneering. Trans. D. R. Schackleton Bailey. London 2002 (The Loeb Classical Library). "Quintus Cicero'dan Consul Adayı Marcus Cicero'ya Mektup: Seçim Öğütleri”. Çev. Ü. F. Telatar - N. B. Ak. Doğu Batı 50, 2009, 127145.

(= Gaius Suetonius Tranquillus, de Vitae Caesarum, Divus Iulius) Kullanılan Metin ve Çeviri: The Lives of Caesars. Trans. J. C. Rolfe. Cambridge - London 1951 (The Loeb Classical Library). Gaius Suetonius Tranquillus, On Iki Caesar'ın Yaşamı. Çev. F. Telatar - G. Özaktürk. Ankara 2018.

S. Akoğlu, "M. Tulli Ciceronis Epistula ad Quintum Fratrem (Q. Fr. I. 1)". Eds. Ç. AşkitS. Kalaycığulları - R. Kayapınar - C. Üstünel Keyinci - R. Öztürk, In Memoriam Filiz Öktem. Ankara (2014) 9-15.

M. C. Alexander, "The Commentariolum Petitionis, As an Attack on Election Campaigns". Athenaeum 97/1 (2009) 31-57.

M. C. Alexander, "M. C. Alexander, "The Commentariolum Petitionis, As an Attack on Election Campaigns". Athenaeum 97/2 (2009) 369-395.

W. Allen, "The British Epics of Quintus and Marcus Cicero". TAPhA 86 (1955) 143159.

D. R. S. Bailey, Cicero Letters to Friends, Volume III. Cambridge, Mass.-London 2001.

D. R. S. Bailey, Cicero Letters to Quintus and Brutus Letter Fragments Letter to Octavian Invectives Handbook of Electioneering. Cambridge, Mass.-London 2002.

D. R. S. Bailey, Cicero: Epistulae ad Quintum Fratrem et M. Brutum. Cambridge 2004. J. P. V. D. Balsdon, "The Commentariolum Petitionis". The Classical Quarterly 13/2 (1963) 242-250

T. C. Brennan, The Praetorship in the Roman Repuplic Vol. II. New York 2000.

F. Bücheler, Quinti Ciceronis Reliquiae. Lipsiae 1869.

E. Courtney, The Fragmentary Latin Poets, edited with Commentary. New York 2003.

J. W. Crawford, M. Tullius Cicero, The Fragmentary Speeches. Atlanta 1994.

J. Dugan, Making a New Man, Ciceronian Self-Fashioning in the Rhetorical Works. Oxford 2005.

A. Eussner, Commentariolum Petitionis examinatum atque emendatum. Würzburg 1872.

Ch. Francese - R. S. Smith, Ancient Rome, An Anthology of Sources. Indianopolis 2014.

E. Gee, “Quintus Cicero's Astronomy?”. The Classical Quarterly 57/2 (2007) 565-585.

R. P. H. Green, The Works of Ausonius: Edited with Introduction and Commentary. Oxford 1991.

E. S. Gruen, The Last Generation of the Roman Republic. Berkeley - Los Angeles London 1974.

M. I. Henderson, "De Commentariolo Petitionis". The Journal of Roman Studies 40/12 (1950) 8-21.

G. L. Hendrickson, "On the Authenticity of the Commentariolum Petitionis of Quintus Cicero". The American Journal of Philology 13/2 (1892) 200-212.

G. L. Hendrickson, Commentariolum Petitionis Attributed to Quintus Cicero, Authenticity, Rhetorical Form, Style, Text. Chicago 1903.

V. L. Holliday, Pompey in Cicero's Correspondence and Lucan's Civil War. Paris 1969. 
Kasten 1965

Kurul - Yılmaz 2018

Laser 2001

Marshall 1975

McDermott 1971

McDermott 1972

Menzilcioğlu 2012

Mommsen 1887

Morstein-Marx 1998

Münzer 1948

Nardo 1970

Nótári 2010

Possanza 1992

Ribbeck 1875

Richardson 1971

Stinchcomb 1932

Syme 1939

Syme 1947

Syme 1958

Tatum 1999

Taylor 1949

Telatar - Ak 2009

Till 1962

Tyrrell 1885

Waibel 1969

Walsh 2008

Watt 1958

Wiseman 1966

Yakobson 1999
H. Kasten, M. Tulli Ciceronis Epistulae ad Quintum Fratrem, Epistulae ad Brutum, Fragmenta Epistularum accedit Q. Tulli Ciceronis Commentariolum Petitionis. München 1965.

E. Kurul - F. Yılmaz, "Bir Devir, Bir Yaşam, Bir Şair: Decimus Magnus Ausonius". Eds. M. Arslan - F. Baz, Arkeoloji, Tarih ve Epigrafinin Arasında: Prof. Dr. Vedat Çelgin'in 68. Doğum Günü Onuruna Makaleler. İstanbul (2018) 559-576.

G. Laser, Quintus Tullius Cicero, Commentariolum Petitionis. Darmstadt 2001.

B. A. Marshall, "Q. Cicero, Hortensius and the Lex Aurelia”. Rheinisches Museum für Philologie 118, $1 / 2$ (1975) 136-152

W. C. McDermott, "Q. Cicero". Historia 20/5-6 (1971) 702-717.

W. C. McDermott, "M. Cicero and M. Tiro". Historia 21/2 (1972) 259-286.

Ç. Menzilcioğlu, Cicero: De Natura Deorum, Tanrıların Doğası. İstanbul 2012.

Th. Mommsen, Römisches Staatsrecht, Dritter Band, I. Abtheilung. Leipzig 1887.

R. Morstein-Marx, "Publicity, Popularity and Patronage in the Commentariolum Petitionis", Classical Antiquity 17/2, 1998, 259-288.

F. Münzer, "Quintus Tullius Cicero". Real-Encyclopädie der classischen Altertumswissenschaft, Band 7A. 2. Stuttgart (1948) 1286-1306.

D. Nardo, I/ Commentariolum petitionis: la propaganda elettorale nella Ars di Quinto Cicerone. Liviana 1970.

T. Nótári, "On Quintus Tullius Cicero's Commentariolum Petitionis". Acta Juridica Hungarica. 51/1 (2010) 35-54.

M. Possanza, "Two Notes on Q Cicero's "De Duodecim Signis" (FPL P. 79 Morel; P. 101 Büchner)". Classical Philology 87/1 (1992) 44-46.

O. Ribbeck, Die Römische Tragödie im Zeitalter der Republik. New York 1875.

J. S. Richardson, "The Commentariolum Petitionis". Historia 20/4 (1971) 436-442.

J. Stinchcomb, "Literary Interests of a Roman Magnate Quintus Tullius Cicero". The Classical Weekly 26/1 (1932) 1-7.

R. Syme, The Roman Revolution. Oxford 1939.

R. Syme, "Latin Pseudepigrapha by E. H. Clift". The Journal of Roman Studies 37 (1947) 198-202.

R. Syme, "Pseudo-Sallust". Museum Helveticum 15/1 (1958) 46-55.

W. J. Tatum, The Patrician Tribune, Publius Clodius Pulcher. London 1999.

L. R. Taylor, Party, Politics in the Age of Caesar. Berkeley - Los Angeles 1949.

Ü. F. Telatar - N. B. Ak, “Quintus Cicero'dan Consul Adayı Marcus Cicero'ya Mektup: Seçim Öğütleri”, Doğu Batı 50, 2009, 127-145.

R. Till, "Ciceros Bewerbung ums Konsulat (Ein beitrag zum commentariolum petitionis", Historia 11/3, 1962, 315-338.

R. Y. Tyrrell, The Correspondence of M. Tullius Cicero, Arranged According to its Chronological Order with a Revision of the Text, a Commentary and Introductory Essays on the Life of Cicero and the Style of his Letters, Vol. I. Dublin 1885.

L. Waibel, Das Commentariolum Petitionis, Unterzuchung zur Frage der Echtheit. (Yayınlanmamış Doktora Tezi). Münschen 1969

P. G. Walsh, Cicero Selected Letters, Translated with an Introduction and Notes. Oxford 2008.

S. W. Watt, M. Tulli Ciceronis epistulae III. Oxford 1958.

T. P. Wiseman, "The Ambitions of Quintus Cicero". The Journal of Roman Studies 56/1-2 (1966) 108-115.

A. Yakobson, Elections and Electioneering in Rome: A Study in the Political System of the Late Republic. Stuttgart 1999. 